\title{
Influence of the surgical manipulation of the colon in colonic induced carcinogenesis in rats
}

\author{
J. F. Noguera Aguilar, I. Amengual Antich¹, A. Plaza Martínez², C. Tortajada Collado³, J. M. Morón \\ Canis $^{3}$ and J. J. Pujol Tugores
}

General Surgery Department. Son Llàtzer Hospital. Son Ferriol. 'Pathology Department. Manacor Hospital Foundation. Manacor. ${ }^{2}$ Vascular Surgery Department. Dr. Peset University Hospital. Valencia. ${ }^{3}$ Son Dureta University Hospital.

Palma de Mallorca

\begin{abstract}
Aim: to investigate the influence of different experimental manipulations in a model of colonic experimental carcinogenesis with pharmacological induction in the rat.

Experimental design: a total of 90 Sprague-Dawley male rats, divided into three groups, were used: non-surgical $(n=30)$; surgical with colonic trauma $(n=20)$, and surgical with colo-colonic anastomosis $(n=40)$. Carcinogenic induction was carried out with 1-2 dimethylhydrazine dihydrochloride. Colonic adenocarcinomas were identified and the number of tumors, as well as tumoral surface and percentage of tumoral surface was established. One-way ANOVA and Chi-square were employed for the statistical analysis.

Results: the number of tumors was greater in the surgical group than in the control group, and tumors preferentially developed around the manipulated colon. Surface and tumoral percentage were greater in the surgical group than in the control group, being also greater in the anastomosis group than in the group with colonic trauma. Within anastomosis groups, a greater tumor surface and percentage was found in the group with titanium than in the group with reabsorbable material.

Conclusions: the experimental manipulation of the colon in rats enhances drug-induced colon carcingenesis. The creation of an anastomosis further increases the carcinogenic process compared with simulated anastomosis. This process is also enhanced by the quantity of suture material included in the anastomosis, and by the non-reabsorbable nature of the materials used in the anastomotic line.
\end{abstract}

Key words: Cancer. Carcinogenesis. Colon. Anastomosis. Rat.

Noguera Aguilar JF, Amengual Antich I, Plaza Martínez A, Tortajada Collado C, Morón Canis JM, Pujol Tugores JJ. Influence of the surgical manipulation of the colon in colonic induced carcinogenesis in rats. Rev Esp Enferm Dig 2004; 96: 322-330.

Recibido: 17-09-03.

Aceptado: 24-11-03.

Correspondencia: José Francisco Noguera Aguilar. Avda. Antonio Maura, 91, bajo 11. 07009 Pont d'Inca. Baleares. e-mail: jnoguera@hsll.es. Tel. 971608244

\section{INTRODUCTION}

Colorectal cancer is the most common digestive cancer in Western Europe and the United States (1), and the second leading cause of death in the Western world (2). In our country, it has an incidence of 20-30 cases per 100,000 inhabitants per year, and is responsible for $20 \%$ of deaths caused by malignancies $(3,4)$. Seventy to $80 \%$ of patients with colorectal cancer will be candidates to surgery with a curative purpose; in the remaining 20-30\% only palliative surgery will be indicated $(5,6)$.

The locoregional recurrence of colorectal cancer is an important problem within the overall recurrence of tumoral illness (7-10). For late anastomotic recurrences, the most adequate explanation may be a metachronous carcinogenesis in the anastomotic zone. This susceptibility of the anastomosis regarding the development of metachronous tumors or local recurrence seems to result from an increased cell proliferation at colonic crypts neighboring the anastomosis area, and to a chronic effect by suture materials employed (11-14).

The importance of this topic is such that experimental standard models permit to assess the results of different manipulations in order to alter the natural history of locoregional recurrences in colorectal cancer $(15,16)$.

The aim of the study was to assess the influence of experimetal colonic manipulation in a model of colonic chemical-induced carcinogenesis in rats. So we aim to determine which experimental maneuvers have a greater influence on this model of carcinogenesis, whether the colonic trauma or the creation of a colo-colonic anastomoses, and to assess the influence of the amount and nature of suture material on the carcinogenesis.

\section{MATERIAL AND METHODS}

Ninety-nine Sprague-Dawley male rats were used (Criffa, Spain), with a mean weight of $185 \mathrm{~g}$. They were divided into three groups: non-surgical or control group 
( $\mathrm{n}=30)$; surgical with colonic trauma $(\mathrm{n}=20)$, and surgical with colo-colonic anastomosis $(n=40)$. In the latter, we differentiate four types of manipulation in the making of the anastomosis: with continuous suture $(n=10)$, interrupted suture $(n=10)$, interrupted suture and addition of reabsorbable material $(\mathrm{n}=10)$, and interrupted suture and addition of non-reabsorbable material $(n=10)$.

Non-absorbible sutures (polyvynildifluoroethylene, monofilament 5/0, Lorca-Marín, Spain) were used for colo-colonic anastomoses. For the addition of reabsorbable material in the anastomotic line, $8 \mathrm{mg}$ of polyglycolic acid in two laminar fragments were used; for the addition of non-reabsorbable material, $8 \mathrm{mg}$ of laminar titanium in two fragments were used.

The carcinogenic induction of colonic neoplasms was carried out with 1-2 dimethylhydrazine dihydrochloride (Sigma-Aldrich, Spain).

\section{Dietary and environmental conditions}

Environmental conditions in the animal storage area were: $12 \mathrm{~h} / 12 \mathrm{~h}$ light/dark cycle (light from 8:00 am - 8:00 pm); uniform temperature at $22 \pm 2{ }^{\circ} \mathrm{C}$, and relative humidity of $60-70 \%$. The diet provided was a maintenance diet A.04 (Panlab, Spain).

The study complied with guidelines established by "Royal Decree" 223/1998, and European Directive 86/609/EEC on the protection of animals used in experimentation.

\section{Anesthetic technique}

A solution of ketamine, atropine and diazepam (50, $10,40 \%$, respectively) was administered intramuscularly at a dose of $4 \mathrm{ml} / \mathrm{kg}$.

\section{Surgical technique}

A midline laparotomy of 3-4 cm in length was performed in the lower part of the abdomen, identifying the site of colonic manipulation at $4 \mathrm{~cm}$ from the anus. In the group with colonic manipulation, a trauma was induced in the first group $(n=20)$ and a colo-colonic end-to-end anastomosis was made in the other group $(n=40)$.

Colonic trauma consisted of a colonic wall trauma simulating a colo-colonic anastomosis; it was performed with eight equidistant passes using the needle and thread with which anastomoses were to be carried out, through the whole thickness of the colonic wall, but without colonic section or leaving suture material in the colonic wall. In the colo-colonic anastomosis group, a complete colonic section was carried out with a subsequent suture using non-reabsorbable 5/0 material. Eight points were equidistantly placed and the intraoperative watertightness of the anastomosis was checked using transrectal pressure.

In the groups in which additional material was added, re- absorbable (polyglycolic acid) or non-reabsorbable (titanium), this was included in the form of two $4 \mathrm{mg}$ filaments lateral to the mesenteric margin, which were anchored in the suture point and thus remained within the colonic wall.

\section{Carcinogenic induction, follow-up and sacrifice}

After eight postoperative days, colonic tumors were induced with 1-2-dimethylhydrazine dihydrochloride (DMH) by administering 18 weekly subcutaneous injections at a weekly dose of $25 \mathrm{mg} / \mathrm{kg}$ of weight. Animals were examined weekly, and special attention was paid to their weight, abdominal perimeter, presence and quality of stools, and presence of rectal bleeding. All animals were sacrificed in postoperative week 20, and their colon was searched for colonic tumors. Animals were killed using an anesthetic overdose, and the entire colon was removed. The colon was divided into two pieces: perianastomotic colon ( $1 \mathrm{~cm}$ above and below the anastomotic line), and the remainder of the colon. Pieces were fixed in a $10 \%$ formaldehyde solution for histologic examination.

\section{Examination of colonic tumors}

Three parameters were determined: number of tumors, tumoral area, and tumoral percentage (percentage of colonic area occupied by tumoral tissue). Only adenocarcinomas were included in the study.

\section{Statistical analysis}

Data obtained were analyzed using the SPSS software program. The statistical analysis was carried out using ANOVA models and Chi-square tables. For the comparison of mean values the ANOVA unifactorial test was used, together with LSD test plus Scheffé or Bonferroni tests.

\section{RESULTS}

\section{Mortality}

Overall mortality in the study included 2 animals out of 90 animals studied, both within the anastomosis group. These deaths resulted from colonic occlusion by induced neoplasms.

\section{Alterations in colonic transit}

Alterations of the gastrointestinal transit because of colonic occlusion occurred in 3 animals (3.33\%). Two of them died and a postmortem study was performed. Third animal sacrificed because of colonic occlusion. Colonic tumors were the cause of intestinal occlusion. 


\section{Number of tumors}

A total of 185 colonic adenocarcinomas were obtained from the 90 animals (2.05 tumors per animal). In the group without surgery, a total of 25 tumors developed $(X=0.83$ tumors per animal); in the group with colonic trauma without anastomosis, 44 tumors were found $(X=2,2)$, whereas in the group with colo-colonic anastomosis, a total of 116 tumors were collected $(X=2.9)$. This difference in mean tumor count between study groups was significant (Fig. 1, p $<0.0005$, ANOVA, LSD and Bonferroni tests).

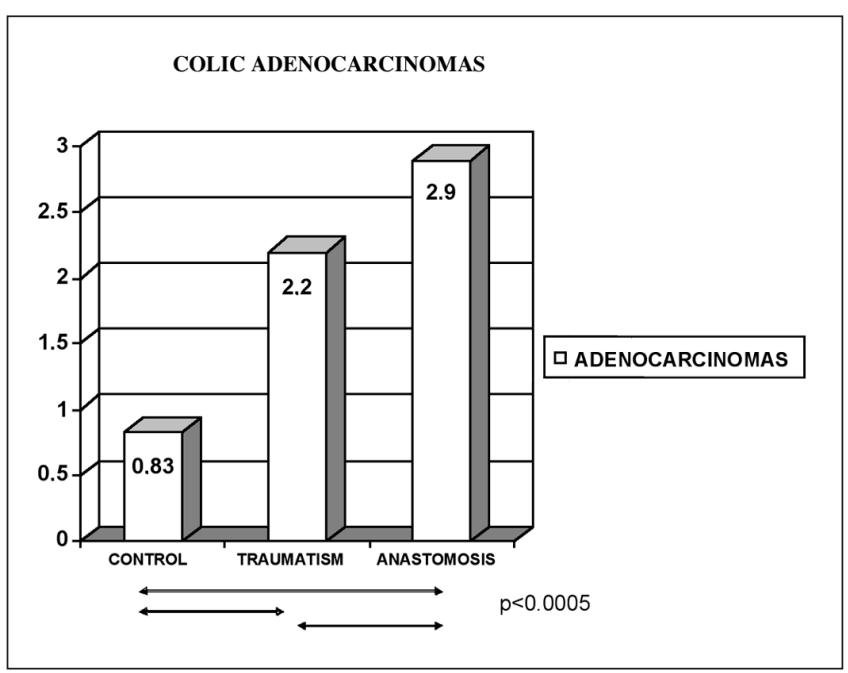

Fig. 1.- Average number of colonic adenocarcinomas found in the different groups.

Medias de los adenocarcinomas cólicos hallados en los distintos grupos.

Regarding colonic tumor location, this varied amongst groups. In the groups without surgery, $64 \%$ of tumors developed in the proximal colon, whereas in the group with colonic trauma without anastomosis, $68.18 \%$ of tumors developed in the proximal colon. When colo-colonic anastomosis was performed, $59.49 \%$ of tumors developed in the perianastomotic area.

\section{Tumoral surface area}

In all, $79.1 \mathrm{~cm}^{2}$ of tumoral colonic area were obtained. In the group without surgery $9.13 \mathrm{~cm}^{2}$ developed $\left(0.30 \mathrm{~cm}^{2}\right.$ per animal), while in the group with colonic trauma $15.64 \mathrm{~cm}^{2}$ were obtained $\left(X=0.78 \mathrm{~cm}^{2}\right.$ per animal), and in the group with colo-colonic anastomosis $54.319 \mathrm{~cm}^{2}$ developed, with an average of $1.36 \mathrm{~cm}^{2}$. Differences between the control group and the group with anastomosis were prominent ( $\mathrm{p}<0.001$, ANOVA, LSD and Scheffé tests), unlike differences between the control and colonic trauma groups (Fig. 2).

If we consider the area with manipulation (with colonic trauma or anastomosis), in the group with colonic trauma $17.64 \%$ of the surface was tumoral in this colonic

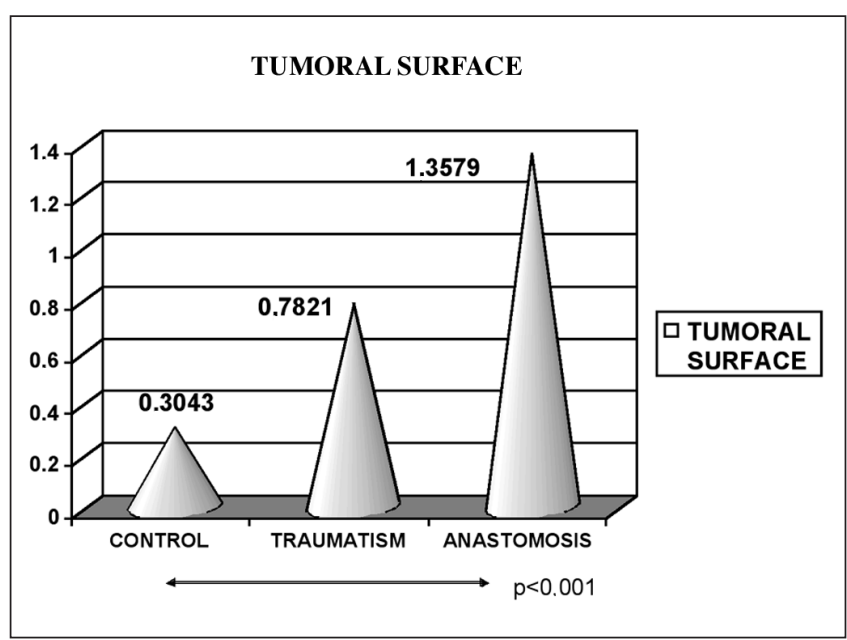

Fig. 2.- Tumoral surface. Measurement in $\mathrm{cm}^{2}$ of the surface occupied by colonic adenocarcinomas; mean values in the different groups. Superficie tumoral. Medición en $\mathrm{cm}^{2}$ de la superficie de los adenocarcinomas cólicos. Se expresa la media de superficie en los distintos grupos.

area, while in the group with anastomosis $62.06 \%$ of the surface was tumoral in the perianastomotic area.

As regards differences obtained between anastomosis subgroups regarding suture material, in the group with continuous suture the average value was $0.9 \mathrm{~cm}^{2}$ per animal, in the group with interrupted suture $1.7 \mathrm{~cm}^{2}$, in the group with titanium $2.2 \mathrm{~cm}^{2}$, and in the group with reabsorbable material $0.6 \mathrm{~cm}^{2}$ (Fig. 3, p $<0.05$, ANOVA, LSD and Scheffé tests).

\section{Tumoral percentage}

Relating the surface of colonic tumoral tissue with the animal's colonic surface the tumoral percentage is obtained. In the group without surgery, this tumoral percentage was $2.99 \%$, while in the group with colonic trauma it increased to $8.63 \%$, with tumoral percentage reaching $23.54 \%$ in the group with colo-colonic anastomosis. Differences between anastomosis and control groups were significant (Fig. 4, $\mathrm{p}<0.0005$, ANOVA, LSD and Scheffé tests).

In the group with colonic anastomosis, the perianastomotic area had $18.65 \%$ of neoplastic tissue, while in the group with trauma this figure was $2.25 \%$ in this area. When the group with colo-colonic anastomosis is considered alone, the highest tumoral percentage appeared in the group with titanium $(39.8 \%)$, followed by the groups with interrupted suture $(27.7 \%)$ and continuous suture $(15.2 \%)$. The group with the smaller percentage of neoplatic tissue was the group with added reabsorbable material (11.1\%) (Fig. 5, $p<0.05$, ANOVA, LSD and Scheffé tests).

\section{Suture material in the anastomotic line}

In the groups in which colo-colonic anastomosis was performed, there was a positive relationship between the 


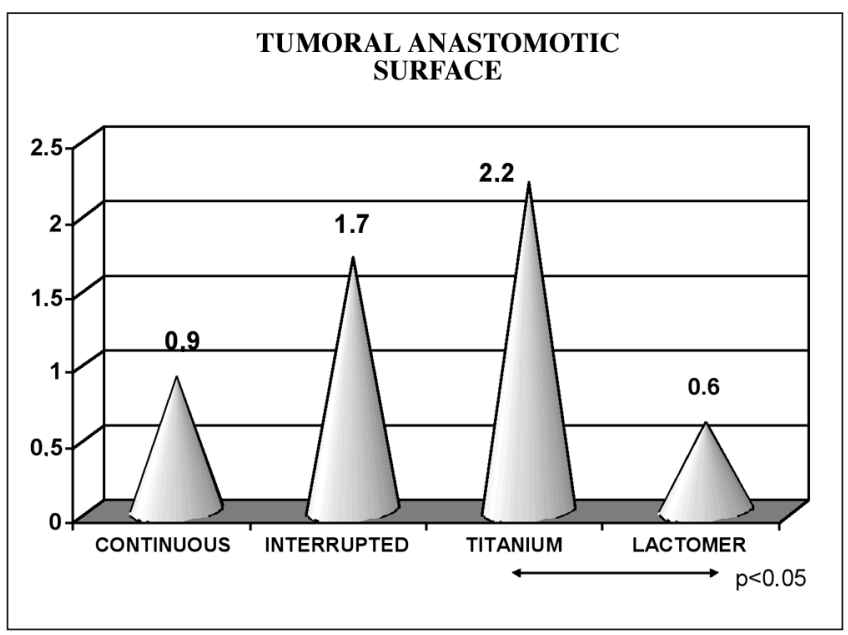

Fig. 3.- Differences in mean values of anastomotic tumoral surface among the different modalities of colonic anastomosis carried out. Diferencias en los valores medios de la superficie tumoral anastomótica entre las distintas modalidades de anastomosis colocólicas realizadas.

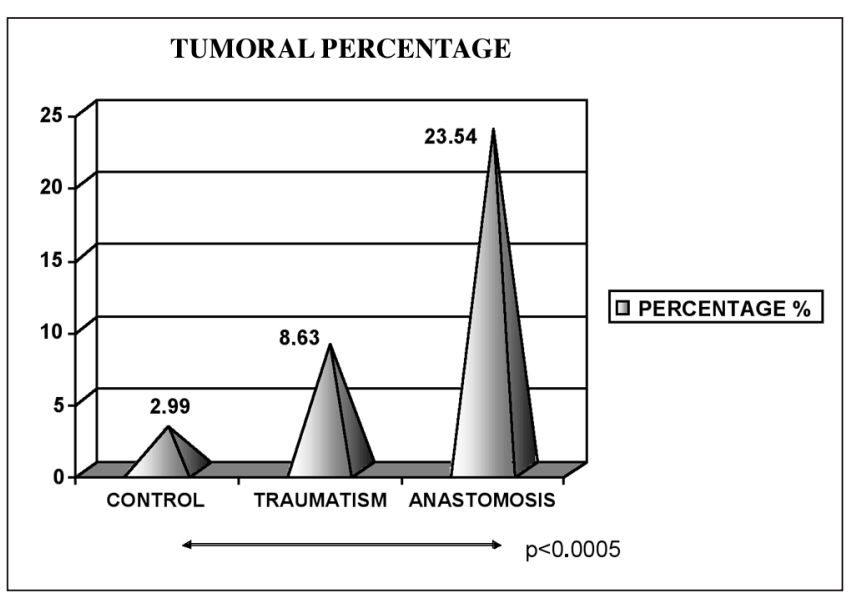

Fig. 4.- Percentage of colonic neoplastic tissue. Mean values for the different groups can be appreciated.

Porcentaje de tejido neoplásico cólico. En la gráfica se puede apreciar la media en los distintos grupos valorados.

length of suture material that remained included in the anastomotic line and the tumoral surface and percentage found in the histological study. The greater quantity of suture material remain included in the anastomotic line, the greater tumoral surface and percentage are found in the histological study. If we consider the group with reabsorbable material added in the anastomotic line, we appreciate that it contains a tumoral surface and percentage smaller than those in the remaining groups, suggesting that this material has a protective effect on colonic carcinogenesis.

\section{Histological study}

Except two cases of adenocarcinoma with signet ring cells $(1.08 \%)$, the rest were non-specific adenocarcinomas. Adenocarcinomas were well differentiated in $56.94 \%$ of ca-

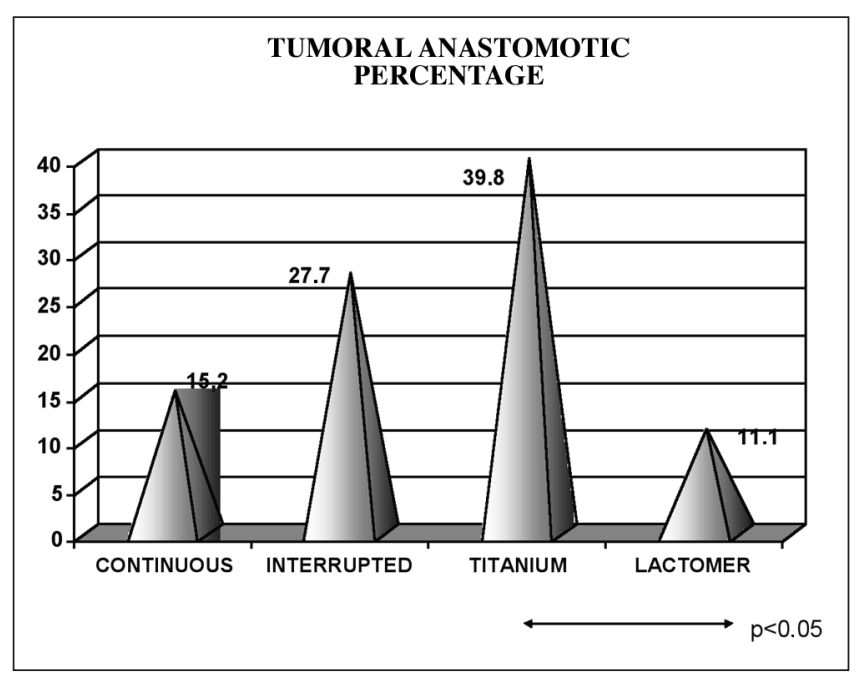

Fig. 5.- Differences in mean values for percentage of perianastomotic tumoral surface among the different modalities of colonic anastomosis. Diferencias en los valores medios del porcentaje de superficie tumoral cólica perianastomótica entre las distintas modalidades de anastomosis colocólicas realizadas.

ses, with moderate differentiation in $35 \%$ and poor differentiation in $8.06 \%$ of cases. Regarding the level of invasion, it reached the submucosa in most cases $(53.33 \%)$; in situ invasion was seen in $30 \%$ and beyond-the-submucosa invasion in $16.66 \%$. If we analize the invasion level in the study groups, we find that tumors are more invasive in the group with colo-colonic anastomosis in comparison with those in the control group ( $\mathrm{p}<0.05$, Chi-square).

A total of 320 pericolonic lymph nodes (3.5 nodes per rat) were collected. Seven of them contained adenocarcinoma micrometastasis. This represents $2.18 \%$ of micrometastases in all nodes evaluated; $3.78 \%$ of adenocarcinomas evaluated had nodal involvement, all of them in the group with colo-colonic anastomosis.

\section{DISCUSSION}

In the present experimental model, experimentally-induced carcinogenesis can neither result from phenomena related to implanted metastases in the manipulated area, nor to a defficient surgical technique, as no previous colonic tumors were present. All experimentally-induced colonic tumors in animals respond to the induction and promotion of the effects of DMH. This effect will be more intense in some groups of animals depending on the experimental variables used.

We analyzed a variety of experimental manipulations to evaluate the effect of colonic manipulation on induced carcinogenesis, either in generic form (surgical group versus control group), or in a specific form (anastomosis versus control and trauma groups; comparison among the different modalities of anastomosis between them).

All postoperative complications and deaths occurred in the surgical group, and more specifically in the group 
with anastomosis. All were due to perianastomotic adenocarcinomas. Global mortality in this study was $2.22 \%$ and the prevalence of intestinal occlusion was $3.33 \%$.

Tumoral colonic proliferation was evaluated using three parameters: number of tumors, surface of colonic tumoral tissue, and percentage of tumoral tissue. The number of tumors is the least reliable of these three indicators because of the wide variability of both the tumor size and the colon size. Tumoral surface is a better approach to the quantity of colonic tissue involved, but percentage of tumoral tissue is the most adequate parameter for the quantification of the carcinogenic process, and therefore for evaluating tumoral surface in relation to the colon size in every animal.

The number of colonic induced tumors was 185 adenocarcinomas. In the group with experimental manipulation, a greater number of tumors developed compared with the control group (2.55 tumors per animal $v s 0.83$ ). This greater prevalence of tumors in the manipulated group was significant. If we consider the control group and the groups with colonic trauma and with colo-colonic anastomosis, differences were also significant.

We observed that experimental colonic manipulation increases the number of pharmacologically-induced tumors when compared with the control group, and that the colocolonic anastomosis induces more tumors than a simulated anastomosis, also causing a clustering of tumors at the perianastomotic area. There were no significant differences in the number of tumors between groups with different modalities of anastomosis.

If we consider tumoral surface, this is greater in the group with experimental manipulation in comparison with the control group, a difference that is prominent. Comparing control, colonic trauma and anastomosis groups, differences are only significant for the group with anastomosis compared with the control one. When we analyze differences among the different modalities of anastomosis, we only found significant differences be-tween the groups with added titanium or reabsorbable material.

While the colo-colonic anastomosis was the experimental manipulation that originated more tumoral surface, the addition of non-reabsorbable material within the anastomotic line clearly contributes to this induction.

Regarding tumoral percentage, a clear and significant increase in colonic tumoral percentage is seen in the

\section{REFERENCES}

1. Arnaud JP, Schloegel M, Ollier JC, Adloff M. Colorectal cancer in patients over 80 years of age. Dis Colon Rectum 1991; 34: 896-8.

2. McGregor JR, Galloway DJ, McCulloch P, George WD. Anastomotic suture materials and implantation metastasis: an experimental study. Br J Surg 1989; 76 (4): 331-4.

3. Domínguez F, Riera JR, Junco P, Tojo S, Díaz-Faes M. Influencia en el pronóstico a corto plazo de la sobreexpresión de la proteína p53 en carcinomas colorrectales. Rev Esp Enferm Dig 1994; 86 (5): 796-802.

4. García JC, Cugat E, Angás J, Gonzalez FJ, Reverter JC, Lacy AM. Cáncer colorrectal: resultados de un protocolo de seguimiento. Cir Esp 1993; 53 (6): 430-3. group with experimental manipulation as compared with the control group. If we separate the manipulated groups into a trauma group and a group with anastomosis, and we compare them with the control group, we obtained identical results as those obtained for tumoral surface; the creation of a colo-colonic anastomosis increases significantly the tumoral percentage versus the control group.

The group with colonic anastomosis presented differences between subgroups. Thus, a greater tumoral percentage was found in the group with added titanium (39.8\%), followed by the groups with interrupted suture $(27.7 \%)$, continuous suture $(15.2 \%)$, and added reabsorbable material $(11.1 \%)$. Differences between the added reabsorbable material and titanium groups were significant.

These differences support that the quantity of material included in the suture line influences the induction and/or promotion of carcinogenesis, and that this phenomenon increases with the amount of non-reabsorbable material included in the anastomosis.

The histological study of tumors shows differences when we assess the invasion extent of adenocarcinomas. In the group with anastomosis, tumors were more invasive than in the control group, but we did not find significant differences between the different modalities of anastomosis.

Regarding metastatic nodal involvement, nodal invasion was only seen at the epicolic nodes in the group with anastomosis. This highlights the fact that performing anastomosis generates more aggressive and invasive tumors than isolated trauma or no surgery.

We may conclude that the experimental manipulation of the colon in rats enhances drug-induced carcinogenesis; the creation of a colo-colonic anastomosis induces a greater increase in the carcinogenic process as compared with the simulated anastomosis. This process of neoplastic induction and promotion in the perianastomotic area is further enhanced by the quantity of suture material included in the anastomosis and by the non-reabsorbable nature of the material implanted in the anastomotic line.

All these experimental situations can promote the carcinogenic process not only regarding intensity, but also playing a role in the nature of this process, inducing more invasive tumors, and showing a greater capacity of causing lymph node metastasis.

5. Tissot E, Naouri A, Nasr JR, Feghali B. Récidives locorégionales isolées des cancers coliques : resultats du traitment, facteurs de risque de ces récidives. Lyon Chir 1992 ; 88 (3) : 277-9.

6. Garcia JA, Morcillo MA, Vázquez JL, Zaragoza C, Moltó M, Cámara J. Cáncer colorrectal en el anciano. Experiencia de los 5 primeros años en un Servicio de cirugía de un hospital Comarcal. Cir Esp 1996; 60: 256-7.

7. Törnqvist A, Ekelund G, Leandoer L. The value of intensive followup alter curative resection for colorrectal carcinoma. Br J Surg 1982; 69: 725-8.

8. Palmer ML, Herrera L, Petrelli NJ. Colorrectal adenocarcinoma in 
patients less than 40 years of age. Dis Colon Rectum 1991; 34: 343-5.

9. Delpero JR, LeTreut YP, Granger F, Pol B, Houvenaeghel G, Brandone JM. Chirurgie des récidives locorégionales des cancers colorectaux. Lyon Chir 1992; 88 (6): 475-82.

10. Pol B, Delpero JR, Le Terut YP, Hardwigsen J, Houvenaeghel G. Resections of colorrectal adenocarcinoma recurrentes: a series of 120 patients. Br J Surg 1996; 83 (2): 32-3.

11. Rubio CA, Nylander G. Surgical resection of the rat colon: effects on carcinogenesis by 1,2-Dimethylhydrazine. JNCI 1982; 68 (5): 813-5.

12. Roe R, Fermor B, Williamson RCN. Proliferative instability and experimental carcinogenesis at colonic anastomoses. Gut 1987; 28: 808-15.
13. Umpleby HC, Williamson RCN. Anastomotic recurrente in large bowel cancer. Br J Surg 1987; 74: 873-8.

14. Appleton GVN, Davies PW, Williamson RCN. El efecto de la desfuncionalización sobre la citocinética y el cáncer en las líneas de sutura del colon. Br J Surg 1990; 77: 768-72.

15. Phillips RKS, Cook HT. Effect of steel wire sutures on the incidence of chemically induced rodent colonic tumours. Br J Surg 1986; 73: 671-4.

16. Calderesi RN. Differential effects of surgical suture materials in 1-2 dimethylhydrazine-induced rat intestinal neoplasia. Cancer Res 1984 44: 2827-30.

\title{
Influencia de la manipulación quirúrgica del colon en la carcinogénesis cólica inducida en ratas
}

\author{
J. F. Noguera Aguilar, I. Amengual Antich¹, A. Plaza Martínez², C. Tortajada Collado³ , J. M. Morón \\ Canis $^{3}$ y J. J. Pujol Tugores
}

Servicio de Cirugía General. Hospital Son Llàtzer. Son Ferriol. ' Servicio de Anatomía Patológica. Fundación Hospital Manacor. ${ }^{2}$ Servicio de Cirugía Vascular. Hospital Universitario Dr. Peset. Valencia. ${ }^{3}$ Hospital Universitario Son Dureta. Palma de Mallorca

\section{RESUMEN}

Objetivo: valorar la influencia de las distintas manipulaciones experimentales en un modelo de carcinogénesis cólica experimental con inducción farmacológica en la rata.

Diseño experimental: se emplearon 90 ratas Sprague-Dawley macho, divididas en tres grupos: no quirúrgico $(n=30)$; quirúrgico con traumatismo cólico $(n=20)$, y quirúrgico con anastomosis colocólica $(n=40)$. La inducción carcinogénica se realizó con 1-2 dimetilhidrazina dihidrocloruro. Se identificaron los adenocarcinomas cólicos y se determinaron número de tumores, superficie tumoral y porcentaje de superficie tumoral. El análisis estadístico se realizó con modelos ANOVA de comparación de medias y con tablas de contingencia Chi cuadrado.

Resultados: el número de tumores fue mayor en el grupo quirúrgico que en el control, apareciendo preferentemente alrededor del colon manipulado. La superficie y el porcentaje tumorales fueron mayores en el grupo quirúrgico que en el control, siendo mayores a su vez en el grupo con anastomosis frente al grupo con traumatismo cólico. Dentro de los grupos con anastomosis, presentó mayor superficie y porcentaje tumoral el grupo con adición de titanio frente al grupo con material reabsorbible.

Conclusiones: la manipulación experimental del colon de la rata aumenta la carcinogénesis cólica farmacológicamente inducida. La creación de una anastomosis provoca un mayor incremento del proceso carcinogénico que la anastomosis simulada. Este proceso se ve además favorecido por la cantidad de material de sutura incluida en la anastomosis y por la naturaleza irreabsorbible de los materiales implantados en la línea anastomótica.

Palabras clave: Cáncer. Carcinogénesis. Colon. Anastomosis. Rata.

\section{INTRODUCCIÓN}

El cáncer colorrectal es el cáncer digestivo más frecuente en Europa Occidental y los Estados Unidos (1) y la segunda causa de muerte en el mundo occidental (2). En nuestro país posee una incidencia de $20-30$ casos por 100.000 habitantes y año, siendo responsable del $20 \%$ de las muertes por procesos malignos $(3,4)$. El 70-80\% de los pacientes con cáncer colorrectal serán candidatos a cirugía con finalidad curativa; en el 20-30\% restante sólo se podrá realizar cirugía paliativa $(5,6)$.

La recurrencia locorregional del cáncer colorrectal es un problema importante dentro de la recidiva global de la enfermedad neoplásica (7-10). Para las recidivas anastomóticas tardías la explicación más adecuada parece ser la de la carcinogénesis metacrona a nivel anastomótico. Esta susceptibilidad de la anastomosis para la aparición de tumores metacronos o recurrencia local parece deberse a la proliferación celular aumentada en las criptas cólicas en vecindad de la anastomosis y al efecto irritante crónico de los materiales de sutura empleados (11-14).

Es tal la importancia del tema que conviene tener modelos experimentales de uso estandarizado que permita valorar los resultados de distintas manipulaciones encaminadas a variar la historia natural de la recidiva locorregional en el cáncer colorrectal $(15,16)$.

El objetivo del estudio es valorar cómo puede influir la manipulación cólica experimental en un modelo de carci- 
nogénesis cólica farmacológicamente inducida en la rata. Se valora además cuáles son las maniobras experimentales que pueden tener más influencia en este modelo de carcinogénesis, si el traumatismo cólico o la creación de una anastomosis colocólica, valorando la influencia de la cantidad de material y de la naturaleza de los materiales de sutura en la carcinogénesis inducida.

\section{MATERIAL Y MÉTODOS}

Se emplearon 90 ratas Sprague-Dawley macho (de Criffa, España), con un peso medio de $185 \mathrm{~g}$. Fueron divididas en tres grupos: no quirúrgico o control $(\mathrm{n}=30)$; quirúrgico con traumatismo cólico $(n=20)$, y quirúrgico con anastomosis colocólica $(n=40)$. En este último subgrupo podemos diferenciar varios tipos de manipulación al realizar la anastomosis: con sutura continua $(n=10)$, sutura discontinua $(n=10)$, sutura discontinua y adición de material reabsorbible $(\mathrm{n}=10)$, y sutura discontinua y adición de material irreabsorbible $(n=10)$.

Para la anastomosis colocólica se empleó material de sutura no absorbible (polivinildifluoroetileno, monofilar 5/0, de Lorca-Marín, España). Para la adición de material reabsorbible en la anastomosis colocólica se emplearon $8 \mathrm{mg}$ de ácido poliglicólico de forma laminar en dos fragmentos; mientras que para la adición de material irreabsorbible se emplearon $8 \mathrm{mg}$ de titanio en forma filamentosa, en dos fragmentos.

La inducción carcinogénica de las neoplasias colónicas se realizó con 1-2 dimetilhidrazina dihidrocloruro (Sigma-Aldrich, España).

\section{Condiciones dietéticas y ambientales}

Las condiciones ambientales del estabulario fueron: periodo luz/oscuridad de 12/12 horas; temperatura de 22 $\pm 2{ }^{\circ} \mathrm{C}$, y humedad relativa del $60-70 \%$. La dieta suministrada fue dieta A.04 (Panlab, España).

Se cumplieron las directrices marcadas por el Real Decreto 223/1998 y por la Directiva de la Unión Europea 86/609/CEE, sobre la protección de animales utilizados para experimentación.

\section{Método anestésico}

Se empleó una solución de ketamina, atropina y diacepam $(50,10,40 \%$ respectivamente), administrado a razón de $4 \mathrm{ml} / \mathrm{kg}$ por vía intramuscular.

\section{Método quirúrgico}

Se realizó laparotomía media de 3-4 cm de longitud en la parte inferior del abdomen, identificando el lugar de manipulación cólica a $4 \mathrm{~cm}$ del ano.

En el grupo con manipulación cólica se realizó trau- matismo cólico en un grupo $(\mathrm{n}=20)$ y anastomosis colocólica término-terminal en el otro grupo $(n=40)$.

El traumatismo cólico consistió en el traumatismo de la pared del colon simulando una anastomosis cólica; se practicaba ocho pasadas equidistantes con la aguja e hilo con que se confeccionaría la anastomosis, pasando por todo el espesor de la pared cólica, pero sin sección cólica ni abandono del material de sutura en el colon. En el grupo con anastomosis colocólica, se procedía a la sección cólica completa con posterior sutura con material irreabsorbible de calibre 5/0. Se colocaban ocho puntos equidistantes y se comprobaba la estanqueidad intraoperatoria de la anastomosis por vía endoanal.

En los grupos en que se añadía material adicional, reabsorbible (ácido poliglicólico) o irreabsorbible (titanio), este era incluido en forma de dos filamentos de $4 \mathrm{mg}$ en las caras laterales al borde mesentérico, anclado en el punto de sutura, quedando así inmerso en la pared cólica.

\section{Inducción carcinogénica, seguimiento y sacrificio}

Los tumores cólicos se indujeron con 1-2 dimetilhidrazina dihidrocloruro (1-2 DMH, de Sigma-Aldrich, España). En el octavo día del postoperatorio los animales recibieron la primera de dieciocho inyecciones subcutáneas semanales de 1-2DMH, a una dosis de $25 \mathrm{mg} / \mathrm{kg}$ de peso.

Los animales eran examinados semanalmente y todos serían sacrificados en la semana 20 postoperatoria. El colon fue dividido en dos piezas: el colon perianastomótico ( $1 \mathrm{~cm}$ por encima y debajo de la línea anastomótica), y el resto del colon. Las piezas fueron fijadas en formol al $10 \%$ para su examen histológico.

\section{Estudio de los tumores cólicos}

Se determinaron tres parámetros: número de tumores, superficie tumoral y porcentaje tumoral (porcentaje de superficie cólica ocupada por tejido tumoral). Sólo los adenocarcinomas fueron incluidos en el estudio.

\section{Análisis estadístico}

Los datos obtenidos se analizaron con el programa informático SPSS. El análisis estadístico se realizó con modelos ANOVA de comparación de medias y con tablas de contingencia Chi cuadrado. Para la comparación de medias con ANOVA se empleó el ANOVA unifactorial con test de LSD más test de Scheffé o Bonferroni.

\section{RESULTADOS}

\section{Mortalidad}

La mortalidad global del estudio fue de 2 animales de los 90 estudiados, pertenecientes al grupo con anastomosis. Estos fallecimientos se debieron a cuadros oclusivos intestinales por las neoplasias inducidas. 


\section{Alteraciones al tránsito cólico}

Aparecieron alteraciones al tránsito digestivo por oclusión cólica en 3 animales (3,33\%). Dos de ellos fallecieron siendo realizado el estudio postmortem, y en un caso se adelantó el sacrificio por oclusión cólica. Los tumores cólicos anastomóticos fueron la causa de los cuadros obstructivos.

\section{Número de tumores}

Se obtuvieron un total de 185 adenocarcinomas cólicos en los 90 animales (2,05 tumores por animal). En el grupo sin intervención quirúrgica aparecieron un total de 25 tumores ( $X=0,83$ tumores por animal); en el grupo con traumatismo cólico sin anastomosis se hallaron 44 tumores $(X=2,2)$, mientras que en el grupo con anastomosis cólica encontramos un total de 116 tumores cólicos $(X=2,9)$. Esta diferencia entre las medias de los tumores en función del grupo de estudio fue significativa (Fig. 1, p $<0,0005$, ANOVA, test LSD y Bonferroni)

En cuanto a la localización de los tumores cólicos, esta fue variable en los distintos grupos. En los grupos sin intervención quirúrgica aparecieron el 64\% de los tumores en el colon proximal y en el grupo con traumatismo cólico sin anastomosis se hallaron el 68,18\% de los tumores en el colon proximal.

Cuando se realizó anastomosis cólica, aparecieron en el área perianastomótica el 59,49\% de los tumores.

\section{Superficie tumoral}

En el conjunto de los animales se obtuvieron $79,1 \mathrm{~cm}^{2}$ de superficie cólica tumoral. En el grupo sin intervención quirúrgica aparecieron $9,13 \mathrm{~cm}^{2}\left(0,30 \mathrm{~cm}^{2}\right.$ por animal), mientras que en el grupo con traumatismo cólico se obtuvieron $15,64 \mathrm{~cm}^{2}\left(\mathrm{X}=0,78 \mathrm{~cm}^{2}\right.$ por animal $)$ y en el grupo con anastomosis colocólica aparecieron $54,319 \mathrm{~cm}^{2}$, con una media de $1,36 \mathrm{~cm}^{2}$. Las diferencias entre el grupo control y el grupo con anastomosis fueron relevantes ( $p<0,001$, ANOVA, test LSD y Scheffé), no siéndolo las diferencias del control con el grupo con traumatismo cólico (Fig. 2).

$\mathrm{Si}$ consideramos el área perimanipulada (bien con traumatismo cólico o con anastomosis), en el grupo con traumatismo cólico se presentó el 17,64\% de la superficie tumoral en esta zona del colon, mientras que en el grupo con anastomosis cólica el $62,06 \%$ de la superficie tumoral asentó en el área perianastomótica.

En cuanto a las diferencias obtenidas en los subgrupos con anastomosis en relación al material de sutura, en el grupo con sutura continua la media fue de $0,9 \mathrm{~cm}^{2}$ por animal, en el grupo con discontinua $1,7 \mathrm{~cm}^{2}$, en el grupo con titanio $2,2 \mathrm{~cm}^{2}$ y en el grupo con material reabsorbible $0,6 \mathrm{~cm}^{2}$ (Fig. 3, p<0,05, ANOVA, test LSD y Scheffé).

\section{Porcentaje tumoral}

Relacionando la superficie de tejido cólico tumoral con la superficie cólica del animal, obtenemos el porcentaje tumoral. En el grupo sin intervención este porcentaje tumoral fue del 2,99\%, mientras que en el grupo con traumatismo cólico alcanzó el 8,63\%, llegando el porcentaje tumoral hasta el $23,54 \%$ en el grupo con anastomosis colocólica. La diferencia entre el grupo con anastomosis y el control fue significativa (Fig. 4, p<0,0005, ANOVA, test LSD y Scheffé).

En el grupo con anastomosis cólica, el área perianastomótica presentó un $18,65 \%$ de tejido neoplásico, mientras que en el grupo con traumatismo se obtuvo un 2,25\% de tejido tumoral en esta área.

Considerando por separado al grupo con anastomosis colocólica, el mayor porcentaje tumoral apareció en el grupo con titanio (39,8\%), seguido por el grupo con sutura discontinua $(27,7 \%)$ y con sutura continua $(15,2 \%)$, siendo el menor porcentaje para el grupo con adición de material reabsorbible $(11,1 \%)$ (Fig. 5, p<0,05, ANOVA, test LSD y Scheffé).

\section{Material de sutura en la línea anastomótica}

En los grupos en que se realizó anastomosis colocólica, existió una relación positiva entre la longitud de sutura que quedaba incluida en la línea anastomótica y la superficie y porcentaje tumoral hallados en el estudio histológico. A mayor cantidad de material de sutura incluido en la línea anastomótica, apareció mayor superficie y porcentaje tumoral cólico.

Si consideramos el grupo con adición de material reabsorbible en la línea anastomótica, apreciamos que presenta menos superficie y porcentaje tumoral que el resto de grupos, mostrando una influencia protectora de este material en la carcinogénesis.

\section{Estudio histológico}

Excepto dos casos de adenocarcinoma en anillo de sello $(1,08 \%)$, el resto fueron adenocarcinomas no específicos. Los adenocarcinomas fueron bien diferenciados en el $56,94 \%$ de los casos, moderadamente diferenciados en $35 \%$ y pobremente diferenciados en el $8,06 \%$ de los casos. En cuanto al nivel de invasión, la mayoría alcanzaban la submucosa $(53,33 \%)$, siendo in situ el 30,00\% y siendo invasores más allá de la submucosa en el 16,66\%. Si relacionamos este nivel de invasión con los grupos de estudio, encontramos que los tumores son más invasivos en el grupo con anastomosis cólica que en el grupo control ( $p<0,05$, Chi cuadrado). Se aislaron un total de 320 ganglios epicólicos (3,5 ganglios por rata), albergando micrometástasis por adenocarcinoma 7 de ellos. Esto supone un 2,18\% de positividad para micrometástasis en los ganglios totales evaluados, y que el 3,78\% de los adenocarcinomas evaluados tenían afectación ganglionar epicólica, todos ellos en el grupo con anastomosis colocólica. 


\section{DISCUSIÓN}

En el presente modelo experimental, la carcinogénesis inducida experimentalmente no puede obedecer a fenómenos de metástasis implantada en el área manipulada, ni a defectos de técnica quirúrgica, pues no se actúa sobre una neoplasia primaria preexistente. Todos los tumores cólicos inducidos experimentalmente en los animales obedecen a un fenómeno de inducción y promoción carcinogénica derivada del efecto de la 1-2 dimetilhidracina. Este efecto será más intenso en unos grupos u otros en función de las variables experimentales que se hayan realizado.

Analizamos una variedad de manipulaciones experimentales frente al grupo control que nos servirá para evaluar la influencia de la manipulación cólica en la carcinogénesis inducida, bien de forma genérica (grupo quirúrgico frente al control), o bien de forma específica (anastomosis frente a control y frente a traumatismo, y comparación de las distintas modalidades de anastomosis entre ellas).

Todas las complicaciones postoperatorias y la mortalidad en el estudio aparecieron en el grupo quirúrgico, y más concretamente en el grupo con anastomosis. Todas ellas debidas a adenocarcinomas perianastomóticos. La mortalidad global en el estudio fue de 2,22\% y la aparición de cuadros oclusivos intestinales fue de 3,33\%.

La proliferación neoplásica cólica se evaluó con tres parámetros; el número de tumores, la superficie de tejido tumoral cólico y el porcentaje de tejido tumoral. El número es el menos fiable de los tres indicadores por la variabilidad en el tamaño de los tumores y en el tamaño del colon del animal. La superficie tumoral se aproxima más a la cantidad de tejido neoplásico inducido, pero es el porcentaje de tejido tumoral el parámetro más adecuado para la cuantificación del proceso carcinogénico, pues evalúa la superficie tumoral en relación al tamaño global del colon de cada animal por separado.

El número de tumores cólicos inducidos fue de 185 adenocarcinomas. En el grupo con manipulación experimental aparecieron mayor número de tumores que en el control (2,55 tumores por animal frente a 0,83$)$. Esta mayor incidencia en el número de tumores en el grupo intervenido fue significativa. Al considerar el grupo control y los grupos con traumatismo cólico aislado y con anastomosis cólica, las diferencias fueron también relevantes.

Apreciamos que la manipulación cólica experimental aumenta el número de tumores inducidos farmacológicamente respecto al grupo control, y que la creación de una anastomosis colocólica origina más tumores que la anastomosis simulada, provocando además un agrupamiento de los tumores inducidos en el área perianastomótica. No se vieron diferencias significativas en el número de tumores entre los grupos con distintas modalidades de anastomosis.

$\mathrm{Si}$ atendemos a la superficie tumoral, observamos que existe mayor superficie tumoral en el grupo con manipulación experimental que en el grupo control, diferencia esta que es relevante. Al comparar los grupos control, traumatismo cólico y anastomosis cólica, las diferencias sólo son valorables para el grupo con anastomosis respecto al control. Al analizar las diferencias entre las distintas modalidades de anastomosis, sólo encontramos diferencias significativas entre los grupos con adición de titanio o de material reabsorbible.

Si la creación de una anastomosis colocólica fue la manipulación que originó más superficie tumoral, la adición de material irreabsorbible en la línea de sutura contribuye claramente en esta inducción.

En lo que respecta al porcentaje tumoral, vemos un claro y significativo aumento en el porcentaje tumoral cólico en el grupo con manipulación experimental frente al control.

Si separamos los grupos intervenidos en grupo con traumatismo y grupo con anastomosis y los comparamos junto al grupo control, se obtiene idéntico resultado que para la superficie tumoral; la creación de la anastomosis cólica aumenta el porcentaje tumoral cólico de manera significativa frente al grupo control.

El grupo con anastomosis cólica presentó diferencias entre sus subgrupos, hallando mayor porcentaje tumoral en el grupo con adición de titanio (39,8\%), seguido por los grupos con sutura discontinua $(27,7 \%)$, sutura continua $(15,2 \%)$ y adición de reabsorbible $(11,1 \%)$. Las diferencias fueron significativas entre los grupos con adición de material reabsorbible frente al grupo con adicion de titanio.

Estas diferencias halladas vienen a reforzar que la cantidad de material incluido en línea de sutura influye en la inducción y/o promoción de la carcinogénesis, y que este fenómeno aumenta cuanto mayor sea el material irreabsorbible incluido en la anastomosis.

El estudio histológico de los tumores muestra diferencias cuando valoramos el nivel de invasión de los adenocarcinomas. En el grupo con anastomosis los tumores son más invasivos que en el grupo control; al considerar por separado las distintas modalidades de anastomosis cólicas, no se apreció influencia en la invasión tumoral.

En relación a la afectación metastásica ganglionar, sólo se halló invasión ganglionar de los ganglios epicólicos en el grupo con anastomosis. Esto refuerza el hecho de que la creación de la anastomosis genera tumores más invasivos y agresivos que el traumatismo aislado o el control sin intervención quirúrgica.

Podemos concluir que la manipulación experimental del colon de la rata aumenta la carcinogénesis cólica farmacológicamente inducida, provocando la creación de una anastomosis colocólica un mayor incremento del proceso carcinogénico que la anastomosis simulada. Este proceso de inducción y promoción neoplásica perianastomótica se ve además favorecido por la cantidad de material de sutura incluido en la anastomosis y por la naturaleza irreabsorbible de los materiales implantados en la línea anastomótica. Todas estas situaciones experimentales pueden favorecer el proceso carcinogénico no sólo en su intensidad, sino influyendo además en la naturaleza de este proceso, induciendo tumores más invasivos y con mayor capacidad de provocar metástasis ganglionares. 